\title{
ESTIMATING THE AMOUNT OF SHIP RECYCLING ACTIVITY USING REMOTE SENSING APPLICATION
}

\author{
M. Watagawa ${ }^{\text {a }}$ T. Shinoda ${ }^{b}$, K. Hasegawa ${ }^{\text {c, }}$ \\ a PASCO Corporation, 1-1-2 Higashiyama, Meguro-ku, Tokyo 153-0043, Japan - (maawsa2507)@pasco.co.jp \\ ${ }^{\mathrm{b}}$ Graduate School of Engineering, Kyushu University, 744 Motooka, Nishi-ku, Fukuoka-city, 819-0395, Japan \\ ${ }^{\mathrm{c}}$ Graduate School of Engineering, Osaka University, 1-2 Yamadaoka, Suita, Osaka 565-0871, Japan
}

Commission VIII, WG VIII/9

KEY WORDS: ALOS, ALOS-2, SAR, Ship Recycling, Remote Sensing

\begin{abstract}
:
The Advanced Land Observing Satellite (ALOS) was launched for earth observation and there are more than 6 million scenes of archives including coastal areas during period of five years. The wealth of satellite imagery is noticeable for investigating monitoring methods such as ship detection in wide ocean area. Especially, it is useful way to estimate past behaviour from satellite imagery compared to reference data. We collected satellite imagery and analysis breaking process in major ship breaking yards between year 2009 and 2011. Comparing the number of recycling ships by satellite imagery to the world statistics is in good agreement. In this study, Remote Sensing Application has been discussed in order to assess the potential to be used for economic activities such as ship recycling in wide coastal area. It was used to evaluate the performance of ship recycling monitoring by Satellite imagery. Additionally, an approach for recognizing ships by SAR imagery regardless of weather conditions is presented.
\end{abstract}

\section{INTRODUCTION}

Ship recycling is the activity of complete or partially dismantling of a ship at ship breaking yard in order to recover components and materials for reprocessing and re-use. Ship breaking industry has been playing a great role in the economy via providing raw materials to steel industry, shipbuilding industry and some other industries. Ship-breaking industries also generate a number of employment opportunities for developing countries. Some existing problem like safety of worker, health and working environment issues drawing negative picture of this industry for the country (Jobaid, 2014). Moreover, the ship scrapping activities contaminate the coastal soil and sea water environment mainly through the discharge of ammonia, burned oil spill, floatable grease balls and lubricants, metal iron and various other disposable refuse materials together with high turbidity of sea water (Islam, 1986). However, it is difficult to carry out in situ measurements to investigate the ship breaking yard of coastal area in world wide. The Advanced Land Observing Satellite (ALOS) was launched for earth observation and there are more than 6 million scenes of archives including coastal areas during period of five years. The wealth of satellite imagery is noticeable for investigating monitoring methods such as ship detection (Watagawa, 2012). Especially, it is useful way to estimate past behaviour from satellite imagery compared to reference data. In this study, Remote Sensing Application has been discussed in order to assess the potential to be used for economic activities such as ship recycling.

\section{SHIP RECYCLING MARKET}

According to Report (UNCTAD, 2014), total demolitions in 2013 were $20 \%$ lower than in the record year 2012. China and South Asia continue dominating the market for ship recycling, together accounting for $92 \%$ of tonnage demolished in 2013 . Bulk carriers accounted for $44 \%$ of the tonnage demolished in
2013 , followed by oil tankers (20\%) and container ships (18\%). Bangladesh had its highest market share in dry-bulk carriers (33\%), China in gas carriers $(65 \%)$, India in container ships $(61 \%)$, and Pakistan in oil tankers (46\%) and offshore vessels (66\%). Figure.1 shows that ship recycling volume by major countries and others from statistics between year 2000 and 2014. It can be seen ship recycling market dominated by major five countries: India, Bangladesh, China, Pakistan and Turky. The authors have focused attention on Satellite imagery to examine estimating ship recycling activity of major ship breaking yards (India and Bangladesh) in the international market.

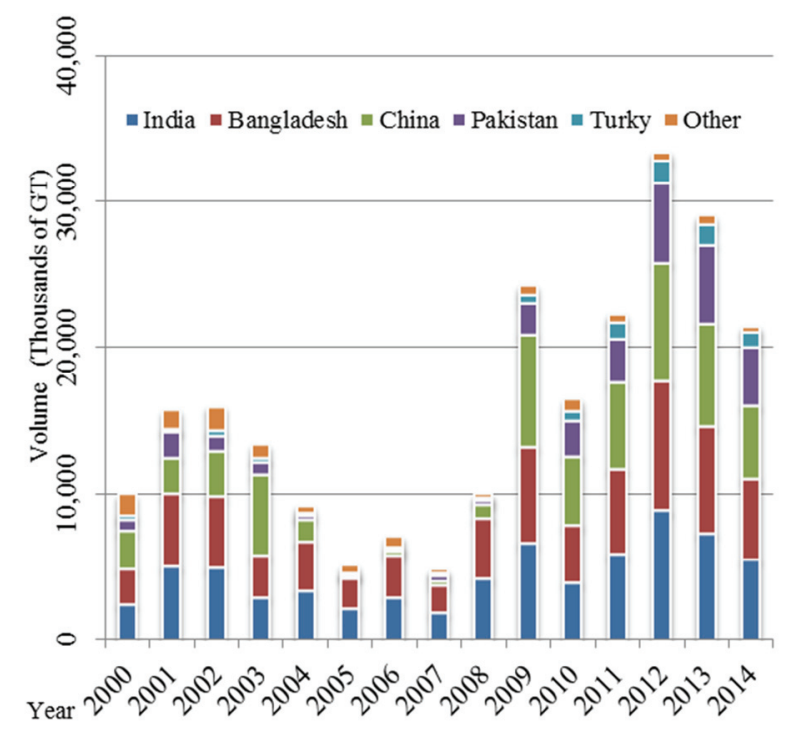

Figure 1. Ship recycling volume of major countries in the international market between year 2000 and 2014, (source of World Casualty Statistics (C) IHS Global Limited) 


\section{METHODOLOGY}

This study proposes a methodology of recycling ships identification in breaking yards by analysis ALOS imagery. We collected time-series ALOS imagery over ship breaking area of major country, India and Bangladesh. In this chapter, our study area, and ALOS imagery are introduced.

\subsection{Major Ship Breaking Yards}

The current ship-breaking majors, located on the Indian subcontinent and South-East Asia, are conveniently close to the majority of trade routes and offer minimum transport distances for many vessels as they can often be stemmed with a cargo for delivery close to the final point of disposal. More than $90 \%$ of global ship recycling activities takes place on the beaches of Bangladesh (Chittagong), India (Alang), Pakistan (Gaddani estate in Baluchistan) and in China (Andersen, 2001).

Major ship breaking yards is geographically located on both side of Indian peninsula (Figure.2). This study focuses on analysis of the ship breaking activities by Satellite imagery in the along the beaches of Alang and Chittagong.

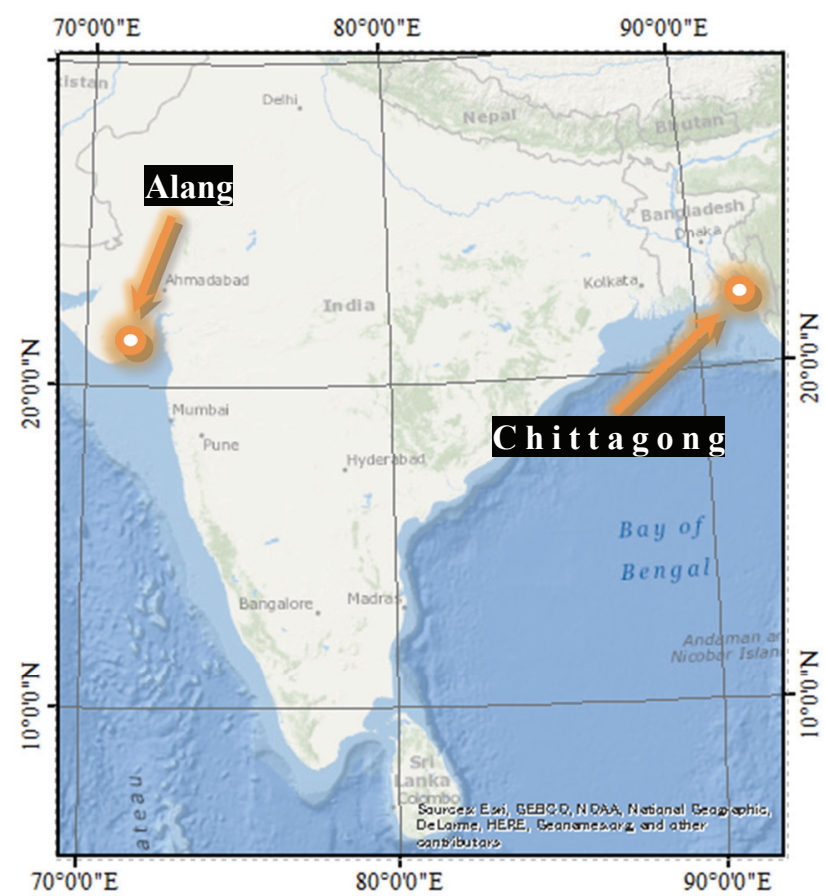

Figure 2. Location of ship breaking yards in India and Bangladesh. CGEBCO, NOAA, National Geographic, DeLorme, and ESRI

\subsection{Time-series Satellite ALOS imagery}

This study focuses on evaluating the potential of ALOS timeseries data to estimate the amount of the ship recycling activity and in the coastal zone. The ALOS has three remote-sensing instruments: the Panchromatic Remote-sensing Instrument for Stereo Mapping (PRISM) for digital elevation mapping with 2.5 $\mathrm{m}$ spatial resolution, the Advanced Visible and Near Infrared Radiometer type 2 (AVNIR-2) for precise land coverage observation with $10 \mathrm{~m}$ spatial resolution, and the Phased Array type L-band Synthetic Aperture Radar (PALSAR) for day-andnight and all-weather land observation (JAXA).

We collected ALOS imagery covering ship breaking yards of each Alang and Chittagong between year 2007 and 2011 for the period are available. Considering the available period and the resolutions of these images, we use ALOS PRISM and AVNIR-
2 as the main imagery source for analysis. Summary of Timeseries ALOS data around each Alang and Chittagong are summarized in Table 1 and Table 2.

\begin{tabular}{|c|c|c|c|}
\hline ID & Scene ID & Acquisition date & $\begin{array}{c}\text { Revisit } \\
\text { day }\end{array}$ \\
\hline 1 & ALPSMW058373170 & $2007 / 2 / 28$ & - \\
\hline 2 & ALPSMW065083170 & $2007 / 4 / 15$ & 46 \\
\hline 3 & ALPSMW071793170 & $2007 / 5 / 31$ & 46 \\
\hline 4 & ALPSMW172443170 & $2009 / 4 / 20$ & 690 \\
\hline 5 & ALPSMN199283170 & $2009 / 10 / 21$ & 184 \\
\hline 6 & ALPSMN219413170 & $2010 / 3 / 8$ & 138 \\
\hline 7 & ALPSMN259673170 & $2010 / 12 / 9$ & 276 \\
\hline
\end{tabular}

Table 1. Acquisition date of ALOS imagery of ship breaking yards around Alang

\begin{tabular}{|c|c|c|c|}
\hline ID & Scene ID & Acquisition Date & $\begin{array}{c}\text { Revisit } \\
\text { days }\end{array}$ \\
\hline 1 & ALAV2A156973150 & $2009 / 1 / 4$ & - \\
\hline 2 & ALAV2A163683150 & $2009 / 2 / 19$ & 46 \\
\hline 3 & ALAV2A177103150 & $2009 / 5 / 22$ & 92 \\
\hline 4 & ALPSMW203943150 & $2009 / 11 / 22$ & 184 \\
\hline 5 & ALPSMW210653150 & $2010 / 1 / 7$ & 46 \\
\hline 6 & ALPSMW217363150 & $2010 / 2 / 22$ & 46 \\
\hline 7 & ALPSMW271043150 & $2011 / 2 / 25$ & 368 \\
\hline
\end{tabular}

Table 2. Acquisition date of ALOS imagery of ship breaking yards around Chittagong

\subsection{Analysis Recycling ships by ALOS imagery}

First approach is counting the number of breaking ships on each acquisition day by time-series ALOS imagery. In the previous study, we found that ALOS imagery can classify vessels structure into categorized vessels (Watagawa, 2012). Several methods were used for extracting ships on ALOS imagery. More specifically, vessel figure were filtered by using spatial search function of GIS. From the results, it can measure shipLOA (Length over All) of more than $65.5 \mathrm{~m}$ vessels within RMSE $6 \mathrm{~m}$ from the ALOS imagery itself. Breaking vessels figure should be recognized by using developed methods. Figure. 3 shows example of counted ships and breaking vessels figure in experimental area in Chittagong.

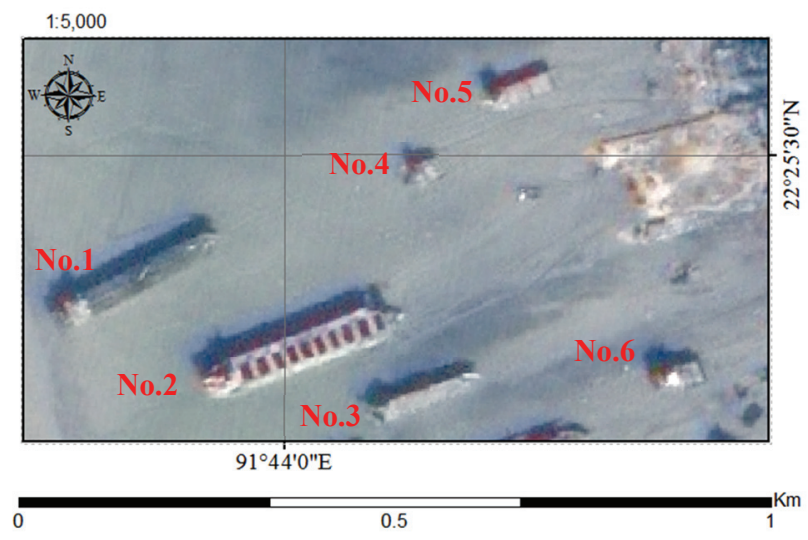

Figure 3. ALOS Pan-sharpen (PRISM/AVNIR-2) imagery capturing breaking-ship figure at 1:5,000 scale CPASCO / Included Material CJAXA 


\subsection{Overview of Ship Breaking Yards}

Beaching is the most common method and is widely used in most places in India, Bangladesh and Pakistan. In the beaching method, the ships are grounded in inter-tidal zone, either under their own power or under tow, during spring tides (Mathesh B, 2016). It should be included each beaching ships of coastal area in Satellite imagery. In this section, a GIS-based prototype maps over ship breaking yards are developed and also reviewed.

\subsubsection{Alang Ship Breaking Yards}

India is the world's leading ship-breaking nation by volume. The activities are centred along the beaches of Alang in the Indian State of Gujarat. This state has a considerable level of industrial activity accounting for some $13 \%$ of total value added in industry to the total economy. The contribution from ship scrapping is considerable (Andersen, 2001).

Figure. 4 shows coverage of experimental area in Alang on October 21, 2009. ALOS PRISM imagery shows $10 \mathrm{~km}$ stretch of the Alang coast where ships are beached and dismantled. Moreover, expanding oil spill from breaking ship is recognized.

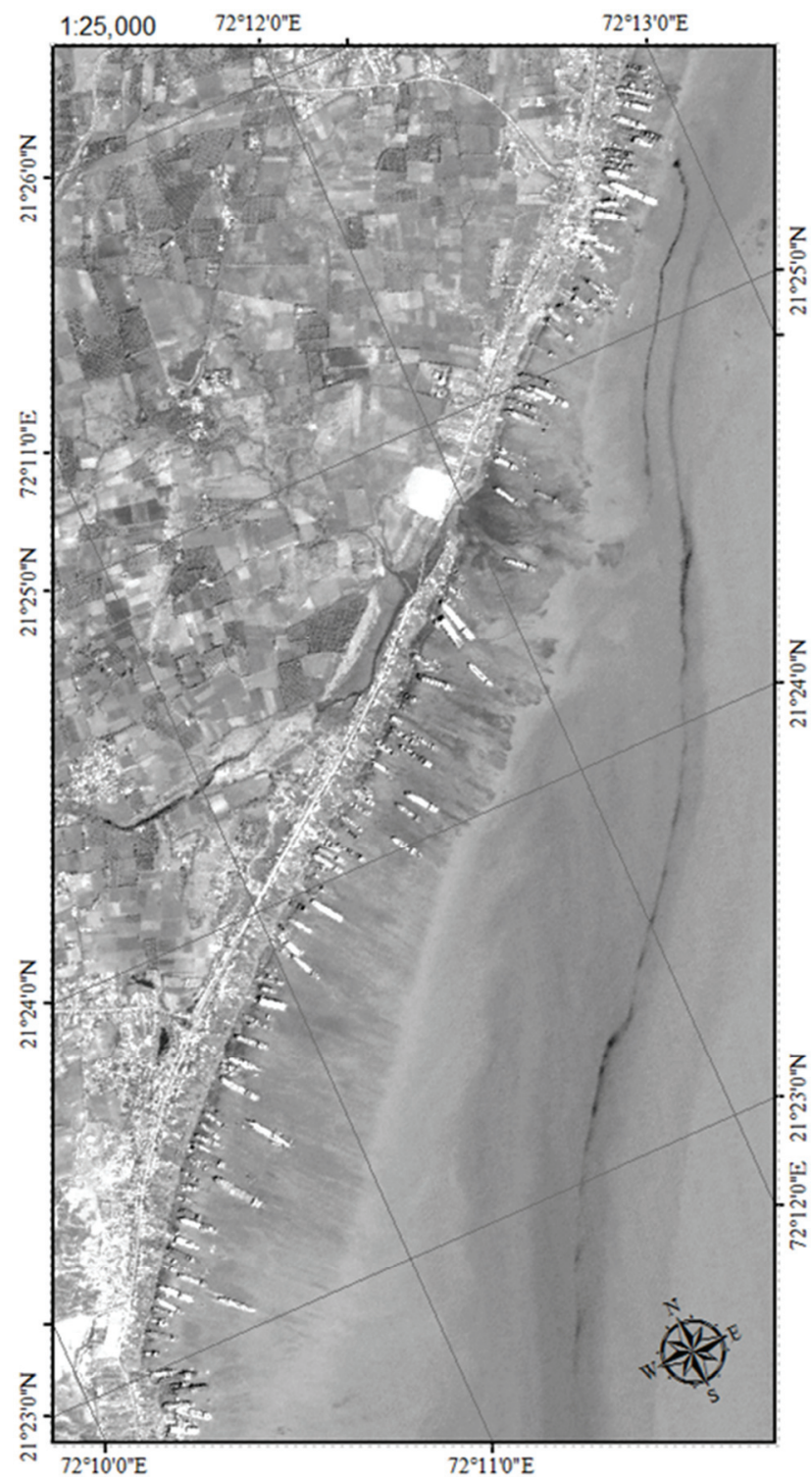

Figure 4. ALOS PRISM imagery capturing ship breaking yards around Alang on October 21, 2009 at 1:25,000 scale CPASCO / Included Material (C) JAXA
3.4.2 Chittagong Ship Breaking Yards

Chittagong is the major ship recycling location in Bangladesh. $16 \mathrm{~km}$ stretch available at Faujdarhat, a city $16 \mathrm{~km}$ southwest of Chittagong where 8 square $\mathrm{km}$ area is available for the recycling related activities. Due to high tidal difference available these yards are suitable for dismantling of big tankers and bulk carriers (Sivaprasad K, 2010).

Figure.5 shows part of experimental area in Chittagong on January 7, 2010. This pan-sharpen ALOS imagery shows about $10 \mathrm{~km}$ stretch of the Bangladeshi coast northwest of Chittagong where ships from around the world are beached.

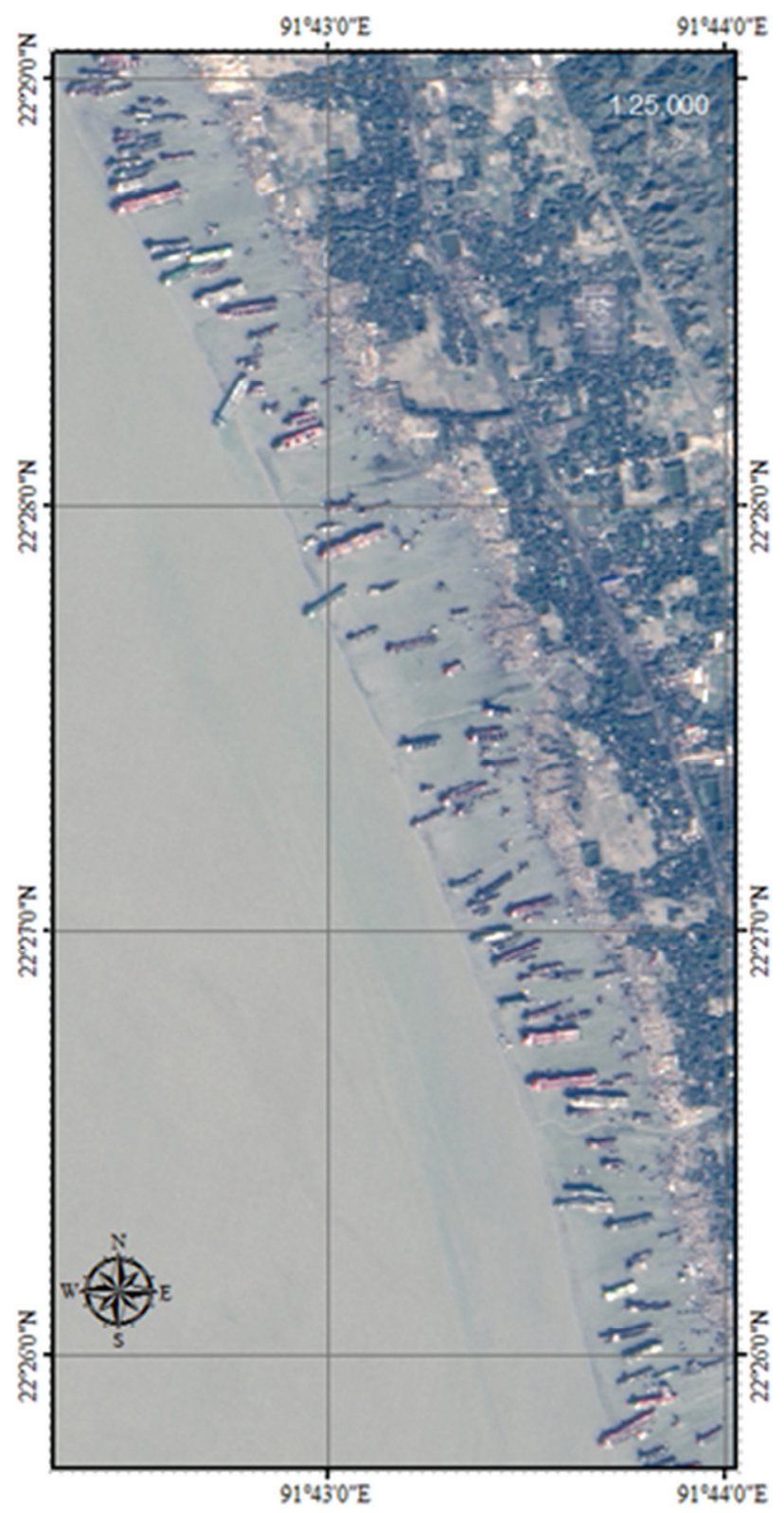

Figure 5. ALOS pan-sharpen (PRISM/AVNIR-2) imagery capturing ship breaking yards around Chittagong on January 72010 at $1: 25,000$ scale CPASCO / Included Material $\mathbb{C}$ JAXA

To analysis ship recycling, GIS-based maps are prepared over both the beaches of Alang and Chittagong by using all available ALOS imagery. 


\subsection{Analysis Ship Breaking Process}

In this section, analytical process is considered to simplify counting the number of breaking ships in ALOS imagery. We extracted ships structure and counting the number of breaking ships on each acquisition day from time-series ALOS imagery. The LOA observed in the ALOS imagery is obtained from those spatial points (bow and stern) of the vessel structure and the measurement was done using GIS calculation tool.
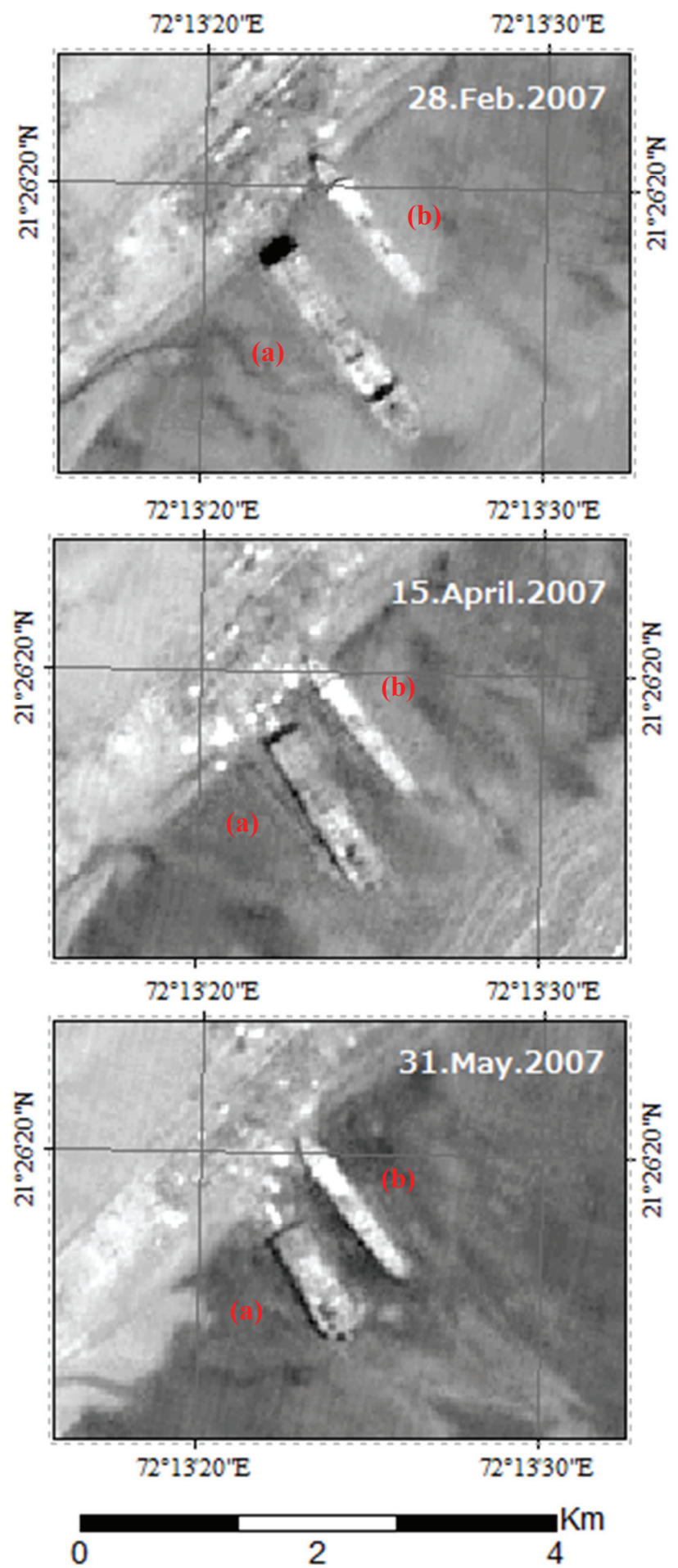

Figure 6. ALOS imagery capturing ship breaking process every 46 days at 1:5,000 scale CPASCO / Included Material (CJAXA
Figure.6 shows that ALOS imagery captured ship breaking process every 46 days from 28 th February 2007 . The vessel (a) and (b) are located on same position in experimental area. The vessel (a) was breaking every 46 days, but the vessel (b) indicated keeping own structure. It estimated the beaching ships are dismantled not less than 3 month vessel. This process would enable to recognize and classify various breaking process. However, we just counted the number of ships or breaking structure in this study.

\section{ESTIMATING THE AMOUNT OF RECYCLING SHIP ACTIVITY}

In order to validate estimating the amount of recycling ships in experimental area from satellite imagery has been evaluated. It has been compared the number of recycling ships by satellite imagery to the total number from world statistics. Additionally, Detecting oil spill from ALOS imagery is indicated.

\subsection{Summary of results}

All of the results are summarized in Table 3 and Table 4. The row of ships from ALOS is the total number from imagery, the row of ships from Statistics is annual number of disposals of each area (Chittagong and Alang).

From this result, recycling ships analysis by ALOS imagery and relativity with statistics. We found a total number of over 100 ships until June from January of year 2009 in Chittagong. Then, total number in end of December 2009 will be approximated equal to the statistics in Chittagong. On the other hand, it seems three times of total number of ships from ALOS will be approximated equal to the statistics in Alang. Comparing the number of recycling ships by satellite imagery to the total number from world statistics indicate to well understand capacity of each country.

\begin{tabular}{|c|c|c|c|c|}
\hline ID & $\begin{array}{c}\text { Acquisition } \\
\text { Date }\end{array}$ & $\begin{array}{c}\text { Revisit } \\
\text { Day }\end{array}$ & $\begin{array}{c}\text { Ships from } \\
\text { ALOS }\end{array}$ & $\begin{array}{c}\text { Ships from } \\
\text { statistics }\end{array}$ \\
\hline 1 & $2007 / 2 / 28$ & - & 45 & \multirow{2}{*}{132} \\
\cline { 1 - 3 } 2 & $2007 / 4 / 15$ & 46 & 49 & \\
\hline 3 & $2007 / 5 / 31$ & 46 & 49 & \multirow{2}{*}{371} \\
\hline 4 & $2009 / 4 / 20$ & 690 & 110 & \multirow{2}{*}{344} \\
\cline { 1 - 3 } 5 & $2009 / 10 / 21$ & 184 & 144 & \\
\hline 6 & $2010 / 3 / 8$ & 138 & 121 & \\
\hline 7 & $2010 / 12 / 9$ & 276 & 83 & \\
\hline
\end{tabular}

Table 3. Total number of recycling ships analysis by ALOS imagery of ship breaking yards around Alang

\begin{tabular}{|c|c|c|c|}
\hline ID & Acquisition Date & Ships from ALOS & \multirow{2}{*}{$\begin{array}{c}\text { Ships from } \\
\text { Statistics }\end{array}$} \\
\hline 1 & $2009 / 1 / 4$ & 105 & \multirow{2}{*}{196} \\
\cline { 1 - 2 } 2 & $2009 / 2 / 19$ & 121 & \\
\hline 3 & $2009 / 5 / 22$ & 137 & \multirow{2}{*}{107} \\
\hline 4 & $2009 / 11 / 22$ & 169 & \\
\hline 5 & $2010 / 1 / 7$ & 140 & 144 \\
\hline 6 & $2010 / 2 / 22$ & 139 & 51 \\
\hline 7 & $2011 / 2 / 25$ & $5 y$ \\
\hline
\end{tabular}

Table 4. Total number of recycling ships analysis by ALOS imagery of ship breaking yards around Chittagong 


\subsection{Detecting oil spill by Imagery}

It is well known that oil spills are a major threat to the coastal environment. Figure.7 shows coverage of experimental area in Chittagong on November 22, 2009. From this ALOS imagery, oil spill from breaking ship indicate $2.7 \mathrm{~km}$ stretch and expanding to south of the coast. We found oil spills from several vessels in Chittagong and Alang by using ALOS imagery. We suggests that it is useful way to recognize location and range of expanding oil spill from satellite imagery more than in situ measurements.

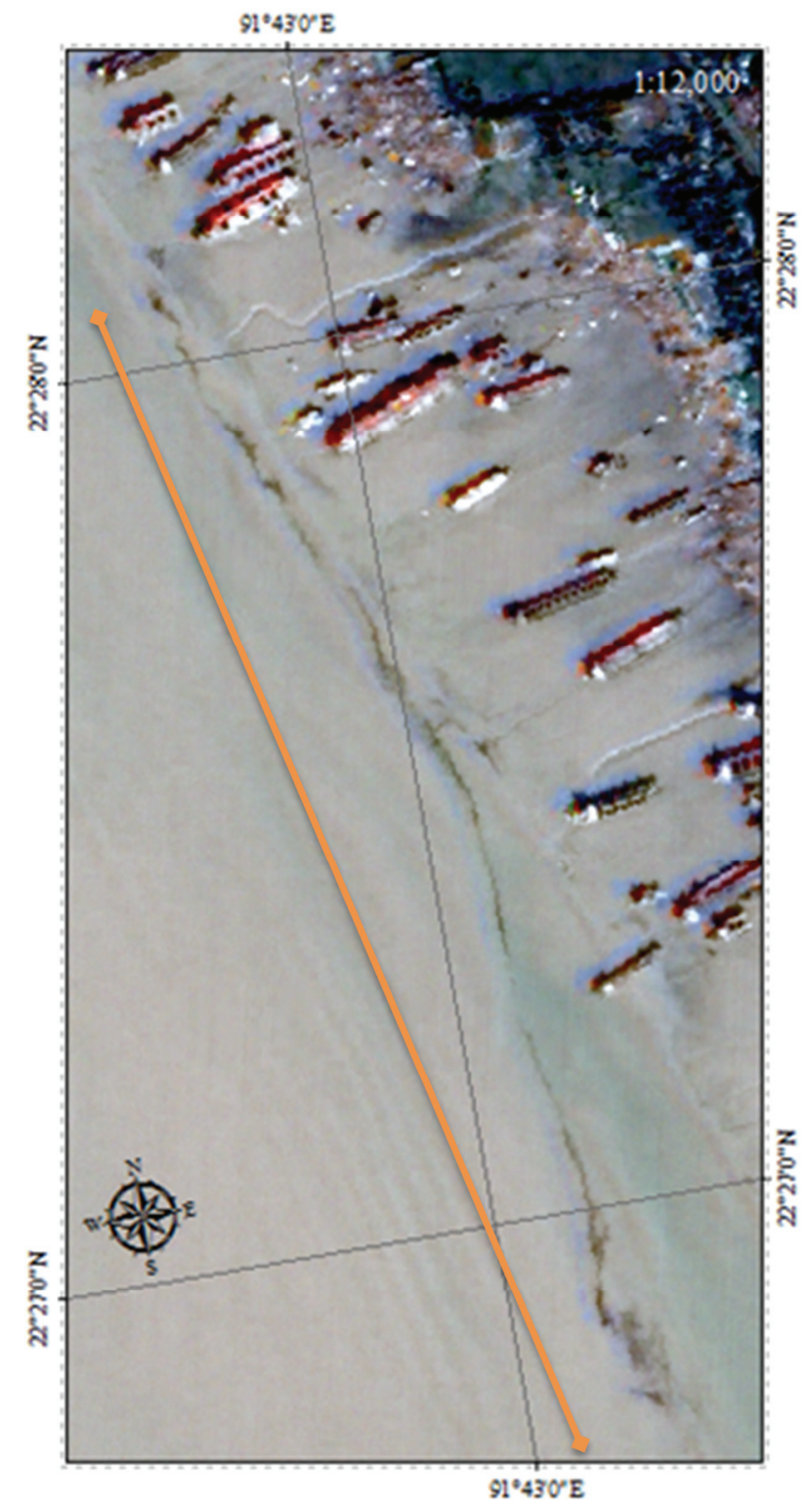

Figure 7. ALOS imagery capturing oil spill from breaking vessel at 1:5,000 scale on November 22, 2009 CPASCO / Included Material CJAXA

\section{FUTURE WORK}

Nowadays, the number of Earth observation Satellite on-board Synthetic Aperture Rader (SAR) sensor. Future work will aim to investigate continuous monitoring of space-born SAR sensors for ship recycling activity.

\subsection{Recycling ships analysis by ALOS-2 imagery}

The ALOS-2 is the successor to the ALOS has been lunched in 2014. Japanese L-band radar keep monitoring for disaster, agriculture, as well as several maritime activity to improve the protection of the marine environment (Watagawa, 2015).

We used the PALSAR-2 imagery of Chittagong was acquired in SM3 (Strip map Fine mode with the resolution of $10 \mathrm{~m}$, swath with of $70 \mathrm{~km}$ ) and DP (Dual Polarization; HH+HV) on 20th February 2015 in ascending pass (23:54 in local time).

Figure. 8 shows example of extracted ships of experimental area in Chittagong from PALSAR-2 color-composite imagery.

The $\mathrm{HH}$ information channel was assigned to red, HV was assigned to green, a third channel is derived from the two polarizations (the $\mathrm{HV} / \mathrm{HH}$ ratio) to create the color-composite image was assigned to blue. Open water, such as rivers, lakes and the seas appear in blue. Green indicates vegetation, light purple and yellowish green are urban areas including building and vessel structure. By analysing false color through the use of polarized wave information, we can understand key land cover types clearly. From this imagery, Strip map mode can be recognized recycling ships.

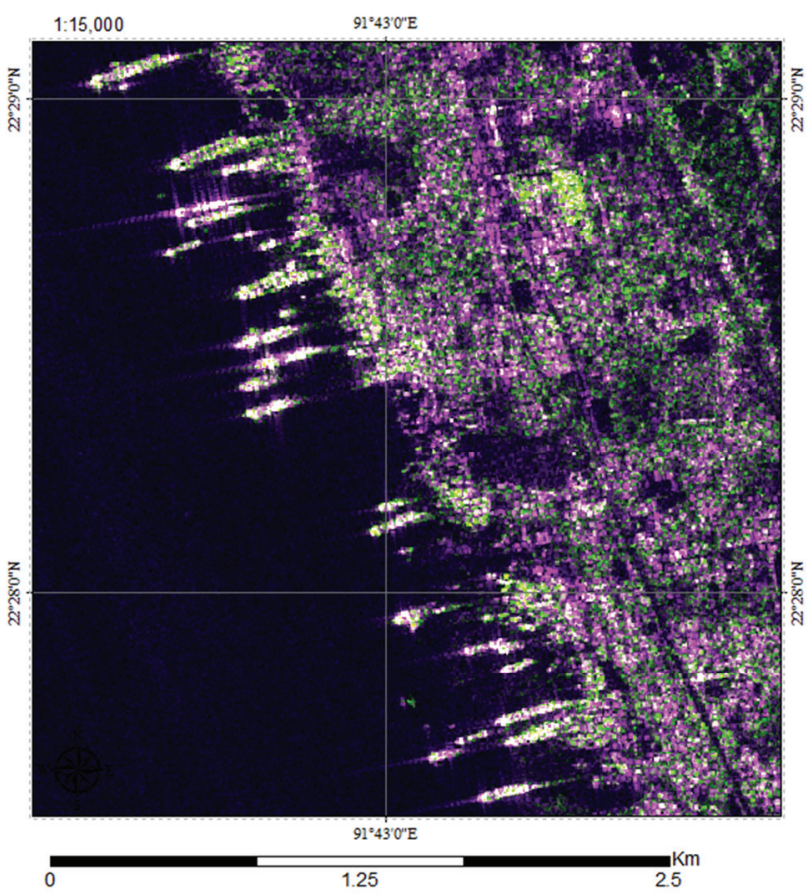

Figure 8. ALOS-2 Strip map mode over the ship breaking yards of Chittagong on February 20, 2015 around acquisition time (23:54, Local Time) at $1: 15,000$ scale. PALSAR-2 color-composite image (Red: HH, Green: HV, Blue: HH/HV) (CJAXA Distributed by PASCO.

\section{CONCLUSION}

In this paper, Remote Sensing Application has been discussed in order to assess the potential to be used for economic activities such as ship recycling. It was used to evaluate the performance of ship recycling monitoring in wide coastal area by Satellite imagery. Additionally, an approach for recognizing ships by SAR imagery regardless of weather conditions is presented. We continue to investigate Optical and SAR sensors for maritime safety. 


\section{ACKNOWLEDGEMENTS}

The author would like to thank JAXA (Japan Aerospace Exploration Agency) for providing experimental ALOS and ALOS-2 imagery. Thanks also to thank Daisuke Sango for helpful suggestions.

\section{REFERENCES}

Md. Imrul Jobaid, Md. Moniruzzaman Khan, A.K.M Kamrul Haque, Istiaque Ahmed Shawon, 2014. Ship Recycling and Its Environmental Impact: A Brief Overview of Bangladesh, IOSR Journal of Business and Management Volume 16, Issue 10.Ver. I (Oct. 2014), PP 31-37.

K.L. Islam, M.M. Hossain, 1986. Effect of Ship Scrapping Activities on the Soil and Sea Environment in the Coastal Area of Chittagong: Bangladesh, Marine Pollution Bulletin Vol. 17. No. I, PP 462-463.

M. Watagawa, E. Kobayashi, N. Wakabayashi, 2012. Monitoring of vessel traffic using AIS data and ALOS satellite image, Proceedings of OCEANS 2012 IEEE ,Yeosu (21-24 May.2012).

United Nations Conference on Trade and Development (UNCTAD), 2014. Review of Maritime Transport 2014, http://unctad.org/en/PublicationsLibrary/rmt2014_en.pdf, pp.46-47, (View Date: Jan 15, 2016).

IHS Global Limited, 2015. DISPOSALS-BY COUNTRY OF BREAKING, World Casualty Statistics 2014, TABLE 7C.

Aage Bjørn Andersen, 2001. Worker safety in the ship-breaking industries, International Labour Office, SECTORAL ACTIVITIES PROGRAMME, WP.167, PP 3-36.

Japan Aerospace Exploration Agency (JAXA), 2015. About ALOS, http://www.eorc.jaxa.jp/ALOS/en/about/palsar.htm (View Date: Jan 15, 2016).

Sivaprasad K, 2010. DEVELOPMENT OF BEST PRACTICES FOR SHIP RECYCLING PROCESSES, A Thesis of Doctor of Philosophy, Cochin University of Science and Technology, KOCHI-682022, PP 13-15.

Mathesh B, Satheesh Babu P K, 2016. Energy Consumption for Ship Dismantling through Beaching Method, IOSR Journal of Mechanical and Civil Engineering (ICETEM-2016), PP 64-67.

M. Watagawa, E. Kobayashi, M. Furusho, 2015. Potential of Maritime Monitoring by using Space-Born Synthetic Aperture Radar, Proceedings of OCEANS 2015, MTS/IEEE, Washington (19-22 Oct.2015). 